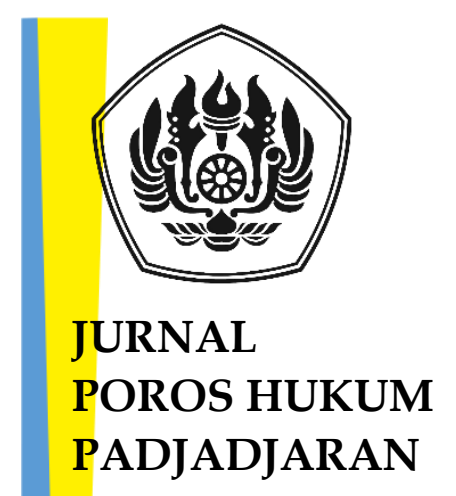

P-ISSN: 2715-7202

E-ISSN: 2715-9418

Artikel diterbitkan:

29 Mei 2020

DOI:

https://doi.org/10.23920/jphp .v1i2.238

Halaman Publikasi: http://jurnal.fh.unpad.ac.id/i ndex.php/JPHP/issue/archive

Diterbitkan oleh:

Fakultas Hukum

Universitas Padjadjaran

\section{KEPASTIAN HUKUM HAK CIPTA ATAS KARYA DESAIN ARSITEKTUR DI INDONESIA DIKAITKAN DENGAN PRINSIP ALTER EGO TENTANG HAK CIPTA}

\section{COPYRIGHT LAW ON ARCHITECTURAL DESIGN WORK IN INDONESIA IS ASSOCIATED WITH THE PRINCIPLE OF ALTER EGO ON COPYRIGHT}

\author{
Muhamad Harismana
}

\begin{abstract}
ABSTRAK
Seiring berkembangan zaman ragam bentuk arsitektur semakin berkembang yang di dorong oleh perkembangan teknologi dan semakin terbatasnya lahan sehingga desain arsitektur dituntut agar dapat menyesuaikan dengan kondisi tersebut. Karya desain arsitektur merupakan bagian dari Kekayaan Intelektual (KI) atau Intellectual Property adalah suatu hak yang timbul bagi hasil pemikiran yangmenghasilkan suatu produk yang bermanfaat bagi manusia. Undang-undang Nomor 28 Tahun 2014Tentang Hak Cipta mengatur mengenai kepemilikan Hak Cipta untuk menjamin hak-hak bagi pemilik hak cipta atas karya arsitektur tersebut, prinsipnya, setiap orang harus memperoleh imbalan bagi buah pikiranya. Hak cipta terdiri atas hak ekonomi dan hak moral, Hak ekonomi adalah hak untuk mendapatkan manfaat ekonomi atas ciptaan serta produk hak terkait. Hak moral adalah hak yang melekat pada diri pencipta atau pelaku yang tidak dapat dihilangkan atau dihapus tanpa alasan apapun, walaupun Hak Cipta atau Hak Terkait telah dialihkan dan Hak moral dan hak ekonomi merupakan hal yang tidak terpisahkan dari prinsip alter ego. Perkembangan ilmu pengetahuan, teknologi, seni, dan sastra, sudah demikian pesat sehingga memerlukan peningkatan pelindungan dan jaminan kepastian hukumbagi pencipta, pemegang Hak Cipta dan apa yang menjadi objek Hak Cipta. Dilindunginya karya arssitektur ini bertujuan untuk menjamin adanya kepastian hukum bagi pencipta karya terutama bagi pencipta karya arsitektur dan perjanjian merupakan alat untuk memperoleh seperangkat hak dan kewajiban perdata, sehingga para pihak memiliki landasan hukum atas apa yang dilakukan arsitek.
\end{abstract}

Kata kunci: hak cipta; kepastian hukum; arsitek; prinsip alter ego

Program Studi Magister Ilmu Hukum, Fakultas Hukum Universitas Padjadjaran, Jl. Banda No. 21 Bandung, email: hafizhlaqarni@gmail.com. 


\begin{abstract}
Along with the development of the diverse forms of architectural development that is driven by technological developments and increasingly limited land so that architectural design is demanded to be able to adjust to these conditions. Architectural design work is part of Intellectual Property (KI) or Intellectual Property is a right that arises for the results of thinking that produces a product that is beneficial to humans.KI can also be interpreted as a right for someone because it has made something useful for others. Law Number 28 Year 2014 Regarding Copyright regulates the ownership of copyrights to guarantee the rights of the copyright owner for the architectural work, especially the rights that arise such as economic rights and moral rights. In principle, everyone must get a reward for his thoughts. Copyright consists of economic rights and moral rights. In principle, everyone must get a reward for his thoughts. Copyright consists of economic rights and moral rights. Economic rights are the rights to obtain economic benefits for the work and related product rights. Moral rights are rights inherent in the creator or perpetrator that cannot be eliminated or deleted without any reason, even though Copyright or Related Rights have been transferred and moral rights and economic rights are inseparable from the principle of alter ego.The development of science, technology, art, and literature, has been so rapid that it requires increased protection and guarantees of legal certainty for the creators, holders of copyrights and what are the objects of copyright. The protection of this architectural work aims to ensure legal certainty for the creators of the works, especially for the creators of architectural works, and the agreement is a tool to obtain a set of civil rights and obligations, so that the parties have a legal basis for what the architect does.
\end{abstract}

Keywords: copyright; legal certainty; architec; the alter ego principle.

\title{
PENDAHULUAN
}

Desain arsitektur adalah salah satu bagian dari karya budaya, sarat dengan makna kehidupan, dan merupakan apresiasi terhadap lingkungan alam sekitar, hingga ekspresi perwujudan seni estetika jiwa manusia. Arsitektur dibangun berdasarkan kaidah - kaidah tradisi yang dianut masyarakat setempat. Arsitektur juga merupakan suatu bentukan dari unsur kebudayaan yang tumbuh dan berkembang bersamaan dengan pertumbuhan suatu suku bangsa sehingga dijadikan sebagai suatu identitas suku bangsa tersebut. Arsitektur adalah suatu bangunan yang bentuk, ragam hias dan cara pelaksanaannya diwariskan turun temurun dari generasi ke generasi. Arsitektur adalah cermin tata nilai dan budaya yang ditradisikan oleh masyarakatnya. ${ }^{1}$ Karya desain arsitektur merupakan bagian dari Kekayaan Intelektual (KI) atau Intellectual Property adalah suatu hak yang timbul bagi hasil pemikiran yangmenghasilkan suatu produk yang bermanfaat bagi manusia. KI bisa juga diartikansebagai hak bagi seseorang karena telah membuat sesuatu yang berguna bagiorang lain. Prinsipnya, setiap orang harus memperoleh imbalan bagi buah pikiranya. ${ }^{2}$

1 Budihardjo, E, 1997, Arsitek dan Arsitek Indonesia Menyosong Masa Depan. Andi, Yogyakarta, hlm. 16

2 Haris Munandar dan Sally Sitanggang, 2008, Mengenal HAKI Hak Kekayaan Intelektual Hak Cipta, Paten dan Seluk beluknya, Erlangga, Jakarta, hlm. 2 
Kekayaan Intelektual merupakan benda tidak berwujud hasil kegiatan intelektual atau daya cipta manusia yang diungkapkan ke dalam suatu bentuk ciptaan atau penemuan tertentu. Kegiatan intelektual terdapat dalam bidang ilmu pengetahuan, seni, dan teknologi. Dari segi hukum, perlu dipahami bahwa yang dilindungi oleh hukum adalah Kekayaan Intelektual, bukan benda material bentuk perwujudan Kekayaan Intelektual. Alasannya adalah Kekayaan Intelektual merupakan Hak Eksklusif yang hanya ada dan melekat pada pemilik atau pemegang hak, sehingga pihak lain apabila ingin memanfaatkan atau menggunakan hak tersebut untuk menciptakan atau memproduksi benda material bentuk jelmaannya wajib memperoleh lisensi (izin) dari pemilik atau pemegang hak. ${ }^{3}$ Arsitek adalah selaku profesional yang merancang pekerjaan untuk kepuasan dan keuntungan para investor, yang didalamnya terdapat perpaduan kecakapan teknik dan kematangan etik yang diperoleh melalui pendidikan, pengalaman dan disiplin yang harus disertai pula mental, etik dan moral yang kuat, tidak hanya sekedar mencari nafkah tetapi juga mempertaruhkan kualitas dan harkat pribadinya. ${ }^{4}$ Hak cipta adalah hak yang dimiliki oleh pencipta atau penerima hak atas suatu hasil karya atau produk yang diciptakan untuk dipublikasikan dengan tujuan melindungi karya atau produk tersebut baik dari segi ekonomi maupun moral. Hak cipta terdiri atas hak ekonomi dan hak moral.

Hak ekonomi adalah hak untuk mendapatkan manfaat ekonomi atas ciptaan serta produk hak terkait. Hak moral adalah hak yang melekat pada diri pencipta atau pelaku yang tidak dapat dihilangkan atau dihapus tanpa alasan apapun, walaupun Hak Cipta atau Hak Terkait telah dialihkan. ${ }^{5}$ Hak moral dan hak ekonomi merupakan hal yang tidak terpisahkan dari prinsip alter ego. Pada dasarnya alter ego adalah prinsip yang meletakkan dasar pengakuan ekonomi maupun hak moral dari pencipta, dan tidak bisa diganggu gugat kepemilikannya terhadap suatu invensi yang diciptakaannya, namun secara umum prinsip alter ego menekankan penghargan yang tinggi kepada pencipta dengan ciptaannya dan melekat pada diri pencipta.Kekayaan intelektual yang timbul dari kemampuan intelektual seseorang, adalah tiada lain dari bentuk perwujudan alter egonya (refleksi kepribadiaanya)

\footnotetext{
${ }^{3}$ Abdul Kadir Muhammad, 2001, Kajian Hukum Ekonomi Hak Kekayaan Intelektual, PT. Citra Aditya Bakti, Bandung, hlm.1.

${ }^{4}$ Eko Budihardjo, 1987, Arsitek Bicara Tentang Arsitektur Indonesia, Alumni, Bandung, hlm. 146

${ }^{5}$ Ermansyah Djaja, 2009, Hukum Hak Kekayaan Intelektual, Sinar Grafika, Jakarta, hlm. 115.
} 
atau perwujudan kualitas rasa, karsa, dan daya nalarnya. Semakin banyak, semakin beragam dan semakin berkualitas kekayaan intelektual yang diciptakan seorang pencipta, di satu pihak akan memberikan nilai tambah terhadap martabat (dignity) dan keuntungankeuntungan materiil atau ekonomi seorang pencipta yang melahirkan suatu kekayaan intelektual bersangkutan, dan di lain pihak akan mencerdaskan kehidupan bangsa pada umumnya. ${ }^{6}$

Undang-Undang Nomor 28 Tahun 2014 Tentang ak CIpta (UUHC) mengatur mengenai kepemilikan Hak Cipta untuk menjamin hak-hak bagi pemilik hak cipta atas karya arsitektur tersebut terutama hak-hak yang timbul seperti hak ekonomi dan hak moral. Sebagaimana dalam Pasal 34 UUCH disebutkan bahwa dalam hal Ciptaan dirancang oleh seseorang dan diwujudkan serta dikerjakan oleh Orang lain di bawah pimpinan dan pengawasan Orang yang merancang, yang dianggap Pencipta yaitu Orang yang merancang Ciptaan. Kemudian di dalam Pasal 35: (1) Kecuali diperjanjikan lain Pemegang Hak Cipta atas Ciptaan yang dibuat oleh Pencipta dalam hubungan dinas, yang dianggap sebagai Pencipta yaitu instansi pemerintah. (2) Dalam hal Ciptaan sebagaimana dimaksud pada ayat (1) digunakan secara komersial, Pencipta dan/atau Pemegang Hak Terkait mendapatkan imbalan dalam bentuk Royalti. (3) Ketentuan lebih lanjut mengenai pemberian Royalti untuk penggunaan secara komersial sebagaimana dimaksud pada ayat (2) diatur dengan Peraturan Pemerintah. Dalam Pasal 36 Kecuali diperjanjikan lain, Pencipta dan Pemegang Hak Cipta atas Ciptaan yang dibuat dalam hubungan kerja atau berdasarkan pesanan yaitu pihak yang membuat Ciptaan.

Salah satu contoh pada perjanjian kerja antara arsitek dengan pengguna jasa arsitek dalam kerangka hubungan kerja yang memperjanjikan bahwa pengguna jasa arsitek diberikan hak untuk memperbanyak atau menggunakan kembali suatu karya desain tanpa perlu meminta ijin penciptanya. Pada dasarnya perlindungan hak cipta yang seharusnya diberikan kepada pencipta melindungi hak moral dan hak ekonomi pencipta namun pada praktiknya perlindungan terhadap hak tersebut tidak terlaksana dengan baik. Hal tersebut bertolak belakang dengan prinsip kepastian hukum yang terdapat Undang-Undang Hak

\footnotetext{
${ }^{6}$ Eddy Damian, 2005, Hukum Hak Cipta, Edisi Kedua Cetakan ke-3, Bandung: Alumni, hlm. 44
} 
Cipta yang telah mengatur dan emberikan perlindungan hukum terhadap Hak Ekonomi dan Hak Moral dari karya desain arsitektur. Kepastian hukum secara normatif adalah ketika suatu peraturan dibuat dan diundangkan secara pasti karena mengatur secara jelas dan logis. Jelas dalam artian tidak menimbulkan keragu-raguan (multi tafsir) dan logis. Jelas dalam artian ia menjadi suatu sistem norma dengan norma lain sehingga tidak berbenturan atau menimbulkan konflik norma. Kepastian hukum menunjuk kepada pemberlakuan hukum yang jelas, tetap, konsisten dan konsekuen yang pelaksanaannya tidak dapat dipengaruhi oleh keadaan-keadaan yang sifatnya subjektif. ${ }^{7}$

Hal tersebut diperkuat menurut penjelasan pasal 36 Kecuali diperjanjikan lain, Pencipta dan Pemegang Hak Cipta atas Ciptaan yang dibuat dalam hubungan kerja atau berdasarkan pesanan yaitu pihak yang membuat Ciptaan. Artinya ketika di perjanjikan lain dalam perjanjian antara arsitek dengan pemesan jasa maka kepemilikan Hak Cipta tersebut dapat beralih. Bila mengacu pada asa Alter Ego maka praktik peraturan perundangundangan dengan asas tidak sesuai. Berdasarkan hal tersebut menjadi latar belakang Peneliti untuk meneliti mengenai “KEPASTIAN HUKUM HAK CIPTA ATAS KARYA DESAIN ARSITEKTUR DI INDONESIA DIKAITKAN DENGAN PRINSIP ALTER EGO BERDASARKAN UNDANG-UNDANG HAK CIPTA."

Permasalahan yangteridentifikasi, yaitu Bagaimana Kepastian Hukum Penerapan Prinsip Alter Ego Atas Kepemilikan Suatu Karya Desain Arsitektur Menurut UndangUndang No. 28 Tahun 2014 Tentang Hak Cipta Dan BagaimanakahImplikasi Penerapan Prinsip Alter Ego Terhadap Perjanjian Kepemilikan Desain Arsitektur Antara Perusahaan Pengembang Dengan Arsitek.

\section{METODE PENELITIAN}

Metode yang digunakan dalam penelitian ini adalahbersifat penelitian deskriptif analitis, yaitu metode yang bertujuan mendeskripsikan atau memberi gambaran terhadap suatu obyek penelitian yang diteliti melalui sampel atau data yang telah terkumpul dan

\footnotetext{
7 Cst Kansil, 2009, Christine, S.T Kansil, Engelien R, Palandeng dan Godlieb N Mamahit, Kamus Istilah Hukum, Jakarta, hlm. 385.
} 
membuat kesimpulan yang berlaku umum. ${ }^{8}$ Sedangkan pendekatan menggunakan YuridisNormatif, yaitu pendekatan atau penelitian hukum dengan menggunakan metode pendekatan/teori/konsep dan metode analisis yang termasuk dalam disiplin Ilmu Hukum yang dogmatis. ${ }^{9}$ Penelitian dengan pendekatan secara yuridis normatif ini menitik beratkan pada norma-norma hukum dan menelaah kaidah hukum yang berlaku. dalam penelitian ini, peneliti akan mengkaji permasalahan yang ada dan mengujinya terhadap peraturan perundang-undangan yang berkaitan dengankedudukan hukum data informasi refensi sebagai pihak ke tiga didalam perjanjian pinjam meminjam uang berbasis teknologi informasi. Tahapan penelitian ini dilakukan dalam dua tahap yang bertujuan untuk mempermudah dalam pengelolaan data, yaitu: Penelitian Kepustakaan (Library research) dan penelitian lapangan.

\section{Kepastian Hukum Penerapan Prinsip Alter Ego Atas Kepemilikan Suatu Karya Desain Arsitektur Menurut Undang-Undang No. 28 Tahun 2014 Tahun 2014 tentang Hak Cipta}

Dalam industri property khususnya perumahan perencanaan tata letak dan tata ruang merupakan hal yang krusial, disamping itu desain arsitektur suatu bangunan rumah juga tidak kalah pentingnya karena mengandung nilai-nilai karya seni yang estetis. Seorang Arsitek memiliki peranan penting dalam menciptakan suatu karya desain arsitektur dalam suatu proyek perumahan. Karya desain arsitektur tersebut dirancang dengan kemampuan olah pikir dan kreatifitas manusia sehingga jadilah sebuah desain arsitektur yang bernilai seni, atas penghargaan terhadap kreatifitas dan olah pikir manusia maka Hak Cipta hadir untuk melindungi kepentingan pencipta suatu karya tersebut. Perlindungan karya cipta hadir dalam rangka melindungi kepentingan hak ekonomi dan hak moral pencipta. perkembangan ilmu pengetahuan, teknologi, seni, dan sastra, sudah demikian pesat sehingga memerlukan peningkatan pelindungan dan jaminan kepastian hukum bagi pencipta, pemegang Hak Cipta dan apa yang menjadi objek Hak Cipta. Objek Hak Cipta adalah Ciptaan yaitu hasil setiap karya Pencipta dalam bentuk yang khas dan menunjukkan keasliannya dalam lapangan ilmu pengetahuan, seni dan sastra. Menurut Pasal 40 ayat (1)

\footnotetext{
${ }^{8}$ Soerjono Soekanto, 1986. Pengantar Penelitian Hukum, UI Press, Jakarta, hlm. 10

${ }_{9}$ Ronny Hanitijo Soemitro, 1990. Metodologi Penelitian Hukum dan Jurimetri, Ghalia Indonesia, Jakarta, hlm. 36
} 
huruf (h) karya arsitektur merupakan objek yang dilindungi oleh UUHC artinya karya desain arsitektur yang merupakan ciptaan dari seorang arsitek sudah terlindungi dengan baik. karena Hak Cipta tersebut berimplikasi kepada hak moral dan hak ekonomi bagi pemilik Hak Cipta tersebut. Dilindunginya karya arssitektur ini bertujuan untuk menjamin adanya kepastian hukum bagi pencipta karya terutama bagi pencipta karya arsitektur yaitu seorang arsitek. Kepastian hukum diartikan sebagai kejelasan norma sehingga dapat dijadikan pedoman bagi masyarakat yang dikenakan peraturan ini. ${ }^{10}$

Pengertian kepastian tersebut dapat dimaknai bahwa ada kejelasan dan ketegasan terhadap berlakunya hukum di dalam masyarakat. Hal agar tidak menimbulkan banyak salah tafsir. Menurut Hans Kelsen, hukum adalah sebuah sistem norma. Norma adalah pernyataan yang menekankan aspek "seharusnya" atau das sollen dengan menyertakan beberapa peraturan tentang apa yang harus dilakukan. Norma-norma adalah produk dan aksi manusia yang deliberative. Undang-Undang yang berisi aturan-aturan yang bersifat umum menjadi pedoman bagi individu bertingkah laku dalam bermasyarakat, baik dalam hubungan dengan sesama individu maupun dalam hubungan dengan masyarakat. Aturanaturan itu menjadi batasan bagi masyarakat dalam membebani atau melakukan tindakan terhadap individu. Adanya aturan itu dan pelaksanaan aturan tersebut menimbulkan kepastian hukum. ${ }^{11}$ Menurut Gustav Radbruch, sebagaimana dikutip oleh Satjipto Rahardjo mengatakan bahwa, "hukum itu harus memenuhi berbagai karya sebagai nilai dasar dari hukum. Nilai dasar hukum tersebut adalah keadilan, kegunaan dan kepastian hukum."12 Kepastian hukum adalah "sicherkeit des Rechts selbst" (kepastian tentang hukum itu sendiri). ${ }^{13}$ Ada empat hal yang berhubungan dengan makna kepastian hukum.Pertama, bahwa hukum itu positif, artinya bahwa ia adalah perundang-undangan (gesetzliches Recht); Kedua, bahwa hukum itu didasarkan pada fakta (Tatsachen), bukan suatu rumusan tentang penilaian yang nanti akan dilakukan oleh hakim, seperti "kemauan baik", "kesopanan"; Ketiga, bahwa fakta itu harus dirumuskan dengan cara yang jelas sehingga menghindari

\footnotetext{
10 Tata Wijayanta, 2014, Asas Kepastian Hukum, Keadilan dan Kemanfaatan Dalam Kaitannya Dengan Putusan Kepailitan Pengadilan Niaga, Fakultas Hukum Universitas Gadjah Mada Yogyakarta, Jurnal Dinamika Hukum Vol. 14 No. 2 Mei 2014, hlm. 219

11 Peter Mahmud Marzuki, 2008, Pengantar Ilmu Hukum, Kencana, Jakarta, hlm. 58.

12 Satjipto Raharjo, 2000. Ilmu hukum, Bandung: Citra Aditya Bakti, hlm. 19.

${ }^{13}$ Idem.
} 
kekeliruan dalam pemaknaan, di samping juga mudah dijalankan; Keempat, hukum positif itu tidak boleh sering diubah-ubah. ${ }^{14}$

Arsitek dapat diartikan sebagai ahli dalam ilmu bangunan, ahli perancang suatu desain bangunan. Arsitek menurut Undang-Undang No. 6 Tahun 2016 Tentang Arsitek adalah seseorang yang melakukan Praktik Arsitek. Adapun yang dimaksud dengan praktik arsitek adalah penyelenggaraan kegiatan untuk menghasilkan karya Arsitektur yang meliputi perencanaan, perancangan, pengawasan, dan/atau pengkajian untuk bangunan gedung dan lingkungannya, serta yang terkait dengan kawasan dan kota. ${ }^{15}$ Sebagai seorang profesional yang merancang desain arsitektur juga sekaligus sebagai pencipta, karena biasanya pencipta suatu ciptaan merupakan pemegang Hak Cipta atas ciptaannya. Dengan kata lain, pemegang Hak Cipta adalah pencipta itu sendiri sebagai pemiik Hak Cipta atau orang yang menerima hak tersebut dari pencipta, dapat disimpulkan pencipta karya desain secara otomatis sebagai pemilik hak cipta berdasarkan prinsip deklaratif sejak ciptaan tersebut dihasilkan dalam wujud nyata. Jole H. O'Gorman menyatakan arsitektur lebih dari sekedar suatupelindung. Arsitektur jadi merupakan suatu wujud seni, namun memilikiperbedaan, yaitu arsitektur menggunakan seni sebagai sesuatu yangpenting untuk digunakan sebagai interior. ${ }^{16}$ Le Corbusier menyatakan bahwa: "architecture is the masterly, correct and magnificient play of masses seen in light. Architecture with a capital A was an emotional and aesthetic experience" ${ }^{17}$

Perspektif yang terdapat pada Hak Cipta menjelaskan bahwa tidak dapat dipisahkan antara pencipta dengan karya ciptanya karena didalam pencipta terkandung unsur hak ekonomi dan hak moral yang melekat pada pencipta, kedua unsur itu bernama hak ekslusif, dikatakan ekslusif karena hak cipta melarang orang lain untuk melakukan hal-hal tersebut tanpa seijin pencipta. Karena itu, pada awalnya hak cipta sering dikatakan berasal dari paham individualisme. Adanya dua unsur seperti hak ekonomi yang artinya hak untuk mendapatkan keuntungan ekonomi atas suatu karya ciptaan, dan hak moral adalah hak yang melekat pada diri pencipta tidak dapat dihilangkan atau dihapus tanpa alasan

\footnotetext{
${ }^{14}$ Idem.

${ }^{15}$ Pasal 1 Ayat (2) Undang-Undang No. 6 Tahun 2016 Tentang Arsitek

${ }^{16}$ J.F. O'Gorman, 1997, ABC of Architecture. Philadelphia: University of Pennsylvania Press, hlm. 34.

${ }^{17}$ Lusi Indah W. 2007. Keragaman Persepsi Terhadap Arsitektur, Jurnal Arsitektur, Vol. 1, No.2, 2007.
} 
apapun, walaupun hak cipta telah dialihkan. Kedua hak tersebut merupakan implementasi prinsip alter ego yang merefleksikan diri pencipta itu sendiri. Pengertian prinsip alter ego adalah prinsip yang meletakkan dasar pengakuan ekonomi maupun hak moral dari pencipta, sehingga pencipta mempunyai hak alamiah untuk memanfaatkan ciptaannya. Pada hakikatnya prinsip alter ego menempatkan inventor sebagai pihak yang tinggi kedudukannya dan tidak bisa diganggu gugat kepemilikannya terhadap suatu invensi yang diciptakannya, namun secara umum prinsip alter ego menekankan penghargaan yang tinggi kepada pencipta dengan ciptaannya dan melekat pada diri pencipta. ${ }^{18}$ secara teori bahwa prinsip alter ego tidak membolehkan karya cipta yang dihasilkan oleh pencipta dialihkan atau dipindah tangankan hak kepemilikanya tetapi hal itu terjadi pada salah satu Pasal 36 UUHC, dalam isi pasal tersebut dijelaskan bahwa Kecuali diperjanjikan lain, Pencipta dan Pemegang Hak Cipta atas Ciptaan yang dibuat dalam hubungan kerja atau berdasarkan pesanan yaitu pihak yang membuat Ciptaan. ${ }^{19}$

Karya cipta desain arsitektur dibuat berdasarkan pesanan dalam hal ini developer perumahan sebagai pemesan jasa arsitek maka pihak pemesan jasa yaitu pihak yang dianggap membuat ciptaan, artinya dalam pasal tersebut memungkinkan kepemilikan hak cipta beralih dari pencipta kepada pihak lain. Kemudian dalam Pasal 5 hak moral yang melekat pada pencipta tidak memungkinkan beralihnya hak moral hal terebut tercantum dalam Pasal 5 UUHC bahwa:

(1) Hak moral sebagaimana dimaksud dalam Pasal 4 merupakan hak yang melekat secara abadi pada diri Pencipta untuk:

a. Tetap mencantumkan atau tidak mencantumkan namanya pada salinan sehubungan dengan pemakaian Ciptaannya untuk umum;

b. Menggunakan nama aliasnya atau samarannya;

c. Mengubah Ciptaannya sesuai dengan kepatutan dalam masyarakat;

d. Mengubah judul dan anak judul Ciptaan; dan

\footnotetext{
${ }^{18}$ Enrico Endy Siagian, Implementasi Prinsip Alter Ego Peneliti Sebagai Hak Ekonomi Paten Aparatur Sipil Negara (ASN) Berdasarkan Undang-Undang Nomor 14 Tahun 2001 Tentang Paten, dalam Jurnal Hukum Unpad

19 Pasal 36 0Undang-Undang No. 28 Tahun 2014 Tentang Hak Cipta.
} 
e. Mempertahankan haknya dalam hal terjadi distorsi Ciptaan, mutilasi Ciptaan, modifikasi Ciptaan, atau hal yang bersifat merugikan kehormatan diri atau reputasinya.

(2) Hak moral sebagaimana dimaksud pada ayat (1) tidak dapat dialihkan selama Pencipta masih hidup, tetapi pelaksanaan hak tersebut dapat dialihkan dengan wasiat atau sebab lain sesuai dengan ketentuan peraturan perundang-undangan setelah Pencipta meninggal dunia.

(3) Dalam hal terjadi pengalihan pelaksanaan hak moral sebagaimana dimaksud pada ayat (2), penerima dapat melepaskan atau menolak pelaksanaan haknya dengan syarat pelepasan atau penolakan pelaksanaan hak tersebut dinyatakan secara tertulis.

Penjelasan pada UUHC, mengatur beberapa hal yang berbeda dari Undang-Undang Nomor 28 Tahun 2014, antara lain: ${ }^{20}$

a. Perlindungan Hak Cipta dilakukan dengan waktu lebihpanjang untuk Hak Cipta di bidang tertentu, yaitudiberlakukan selama hidup pencipta ditambah 70 (tujuhpuluh) tahun setelah pencipta meninggal dunia;

b. Penyelesaian sengketa secara efektif melalui prosesmediasi, arbitrase atau pengadilan, serta penerapan delikaduan untuk tuntutan pidana; dan

c. Hak Cipta sebagai benda bergerak tidak berwujud dapat dijadikan objek jaminan fidusia

Sebagaimana pandangan Gustav Radbruch mengenai nilai dasar hukum yang dikaitkan dengan perlindungan aspek alter ego hak cipta dalam bidang arsitektur, sebagaimana berikut:

a. Harus adanya peraturan perundang-undangan yang bersifat positif, agar dapat diukur berdasarkan daya mengikat dan berlakunya suatu aturan dalam pembahasan ini adalah UUHC;

b. Hukum yang telah terhimpun dalam peraturan perundang- perundangan harus didasarkan pada fakta, bukan pandangan subyektif hakim karena keterbatasan kemampuannya dalam bidang objektif. Apabila kita hubungkan dengan

\footnotetext{
${ }^{20}$ Reni Budi Setianingru, 2016, Mekanisme Penentuan Nilai Ekonomis dan Pengikatan Hak Cipta Sebagai Objek Jaminan Fidusia, Media Hukum, Vol. 23 No. 2, Desember, 2016, hlm. 231.
} 
pembahasan ini, adapun yang melatarbelakangi adanya perlindungan dan pengaturan teradap hak ekonomi maupun ak moral pada arsitektur yaitu karena adanya prinsip alter ego yang merupakan prinsip dasar pada pengakuan hak ekonomi maupun hak moral dari pencipta, sehingga pencipta mempunyai hak alamiah untuk memanfaatkan ciptaannya, menempatkan inventor sebagai pihak yang tinggi kedudukannya dan tidak bisa diganggu gugat kepemilikannya terhadap suatu invensi yang diciptakannya. Adanya pengaturan dan perlindungan terhadap dua aspek penting tersebut dalam arsitektur merupakan upaya untuk mengakomodir kebutuhan atau fakta - fakta dalam masyarakat.

c. Fakta - fakta sebagaimana dijelaskan dalam poin b, harus disusun secara sistematis agar terjaminnya pemenuhan hak pencipta (dalam hal ini arsitek).Berkenaan dengan perlindungan dan pengaturan pinsip alter ego, hak moral pada Pasal 5 UUHC dan hak ekonomi pada Pasal 6 UUHC.

d. Hukum positif tidak boleh sering dirubah - rubah, namun hal ini tidak bersifat mutlak. Tidak boleh sering di rubah - rubah bermaksud untuk memberikan suatu indikator kualitas daripada suatu peraturan perundang-undangan yang dibentuk, dengan memproyeksikan arah pembangunan masyarakat. Dengan kata lain, hukum berada jauh di depan untuk mengarahkan, membimbing, dan memberikan pengertian pembangunan dalam kehidupan masyarakat.

Jika mengacu kepada prinsip alter ego yang menjunjung tinggi kepemilikan hak cipta melekat pada pencipta maka dalam Pasal 36 Undang-Undang Nomor 28 Tahun 2014 Tentang Hak Cipta terebut kurang sesuai dengan prinsip alter ego yang seharusnya dijadikan rujukan dalam pembentukan undang-undang. Disamping itu walaupun hak ekonomi dapat dialihkan namun untuk hak moral yang melekat pada pencipta tidak dapat dialihkan karena hak moral adalah hak yang bersifat manunggal antara ciptaan dengan pencipta, dapat dikatakan integritas dari pencipta. Hak moral suatu hak cipta dapat mencakup hak untuk mencantumkan nama pencipta dalam ciptaanya. Hak moral merupakan hak yang tidak dapat dialihkan sehingga hak moral selalu terintegrasi dengan pencipta. 
Implikasi Penerapan Prinsip Alter Ego terhadap Perjanjian Kepemilikan Desain Arsitektur antara Perusahaan Pengembang dengan Arsitek

Perjanjian atau kontrak adalah suatu peristiwa di mana seorang atau satu pihak berjanji kepada seorang atau pihak lain atau di mana dua orang atau dua pihak itu saling berjanji untuk melaksanakan suatu hal. ${ }^{21}$ Dalam hal ini para pihak yang dimaksud adalah Arsitek dengan pengguna jasa yakni perusahaan bergerak dibidang property. Dalam kerangka hubungan kerja antara arsitek dengan pengembang property keduanya saling mengikatkan diri pada suatu perjanjian yang memuat hak dan kewajiban seorang arsitek serta hak dan kewajiban pihak pengembang property sebagai pihak pengguna jasa sehingga bilamana terjadi perselisihan dikemudian hari dapat dihindari.Perusahaan perencana konstruksi (sebagai majikan)tidak pernah membuat perjanjian dengan arsitek (sebagai pekerja) tentangkepemilikan hak cipta arsitektur. Namun kenyataannya semua hasil ciptaanarsitektur tersebut tetap menjadi milik perusahaan. Bahkan ketika arsiteknya tidak bekerja di perusahaannya lagi, ciptaan arsitekturnya masih tetap digunakan untukdiwujudkan dalam bentuk bangunan tanpa memberikan fee atau royalti. Statuskepemilikan hak cipta arsitektur menjadi tidak jelas ketika didalam kontrak kerjatidak memuat klausul tentang kepemilikan hak cipta. Dalam prakteknya banyak yangberanggapan Perusahaanlah yang berhak karena telah memberi gaji, tapi undangundang menentukan hak cipta itu melekat pada penciptanya (arsitek) kecuali apabiladiperjanjikan lain antara kedua belah pihak. Terdapat perbedaan antara ketentuanundang-undang dengan prakteknya dilapangan, ketika ciptaan arsitektur dibuatdalam suatu hubungan kerja, dalam prakteknya menjadi tidak jelas pihak mana yangberhak atas kepemilikannya. Siapa yang sebenarnya berhak disebut sebagai penciptaatau pemegang hak cipta pada suatu arsitektur ${ }^{22}$.

Ada pun hak dan kewajiban seorang arsitek memperoleh jaminan perlindungan hukum selama melaksanalan Praktik Arsitek sesuai dengan kode etik profesi Arsitek dan standar kinerja Arsitek di Indonesia, memperoleh informasi, data, dan dokumen lain yang

\footnotetext{
${ }^{21}$ Pasal 1313 Kitab Undang-Undang Hukum Perdata Indonesia

22 Yasir Arfan, 2013. Status Kepemilikan Hak Cipta Arsitektur yang dibuat Berdasarkan Hubungan Kerja (Suatu Penelitian di Kota Medan). Premise Law Jurnal. Vol 1, No 2 (2013), hlm.4.
} 
lengkap dan benar dari Pengguna Jasa Arsitek sesuai dengan keperluan dan ketentuan peraturan perundang-undangan mendaftarkan hak kekayaan intelektual atas hasil karyanya, menerima imbalan hasil kerja sesuai dengan perjanjian kerja; dan mendapatkan pembinaan dan kesempatan dalam meningkatkan kompetensi profesi Arsitek. ${ }^{23}$ Sedangkan kewajiban seorang arsitek adalah melaksanakan Praktik Arsitek sesuai dengan keahlian, kode etik profesi Arsitek, kualifikasi yang dimiliki, dan standar kinerja Arsitek menyelesaikan pekeg'aan sesuai dengan perjanjian kerja dengan Pengguna Jasa Arsitek. ${ }^{24}$ Kerangka hubungan kerja antara arsitek dengan developer timbul suatu hubungan hukum yang diikat dalam perjanjian kerja antara arsitek dengan pengembang property yang saling mengikat sebagaimana dalam Pasal 1313 Kitab Undang-Undang Hukum Perdata. Karena adanya pihak yang mengikat maka konsekuensi dari hal tersebut adalah adanya prestasi dari para pihak. Prestasi adalahmerupakan hal yang harus dilaksanakan dalam suatu perikatan. Pemenuhan prestasi merupakan hakikat dari suatu perikatan. Kewajiban memenuhi prestasi selalu disertai dengan tanggung jawab (liability).

Perjanjian merupakan alat untuk memperoleh seperangkat hak dan kewajiban perdata, sehingga para pihak memiliki landasan hukum atas apa yang dilakukan. Dalam perjanjian Pekerjaan Jasa Konsultasi Perencanaan Teknis Terinci Pekerjaan Arsitektur (PJKPTT-PA) antara PT. CRN sebagai pihak pertama dengan PT. RI sebagai pihak kedua yang memuat hak dan kewajiban tugas dan ruanglingkup pekerjaan dalam Pasal 2 ayat (1) dan ayat (2) sebagai berikut:

(1) PIHAK KESATU memberikan tugas kepada PIHAK KEDUA dan PIHAK KEDUA menerima tugas dari PIHAK KESATU, untuk melaksanakan Jasa KonsultansiPerencanaan Teknis Terinci Pekerjaan Arsitektur denganlingkup sebagai berikut:

a. Memahami tujuan dan latar belakang Rencana Pengembangan Proyek sesuai dengan pengarahan Pihak Pemberi Tugas

\footnotetext{
${ }^{23}$ Pasal 21 Undang-Undang Nomor 6 Tahun 2016 Tentang Arsitek

24 Pasal 22 huruf a \& b Undang-Undang Nomor 6 Tahun 2016 Tentang Arsitek
} 
b. Mengumpulkan data-data/referensi yang relevan dengan konteks Perencanaan Proyek dan Survey lapangan ke Lahan Proyek, mengamati situasi dan kondisi lingkungan, serat kualitas atmosphere fisik proyek

c. Review dan evaluasi hal-hal di atas untuk mengajukan usulan Tema Desain/Konsep Perencanaan Proyek menyeluruh. Solusi desain arsitektur sesuai kebutuhan Pemberi Tugas

d. Bekerja sama, mengkoordinir pekerjaan Perencanaan Master Plan dan/atau Desain Arsitektur

e. Memberikan nasihat/input-inputyangberkaitan dengan rencana pengembangan proyek terutama dalam hal menghasilkan suatu Alternatif Master Plan/Desain Arsitektur yang paling optimal sesuai kebutuhan dan sasaran pihak Pemberi Tugas

(2) Pekerjaan Jasa Konsultasi akan dilaksanakan oleh PIHAK KEDUA dengan tahapan sebagai berikut:

a. Tahap Penyusunan Konsep Desain, yang terdiri dari:

1) Tata letak massa bangunan \& ruang terbuka serta respon lingkungan

2) Rencana sirkulasi kendaraan, pedestrian, dan entrance bangunan

3) Rencana zoning fungsional tapak dan dalam bangunan

4) Tabel kalkulasi Gross Floor Area dan Efective Area

5) Rencana kapasitas penggunaan lahan (Luas bangunan, KDB, KLB, Tinggi Bangunan)

6) Tema spesifik fungsi dan bentuk/penampilan bangunan

7) Perspektif eksterior/interior bangunan

b. Tahap Penyusunan Skematik Desain, yang terdiri dari:

1) Gambar-gambar skematik denah setiap lantai bangunan

2) Tampak dan potongan skematik bangunan

3) Layout dasar system Struktur dan M/E bangunan dan site

4) Gambar keteknikan mengacu pada peraturan bangunan (TPAK/TPKB/TPIB)

5) Produk-produk perencanaan yang dibutuhkan untuk proses perijinan, dengan batasan ukuran kertas gambar kerja A3. 
6) Bilamana proses perijinan mensyaratkan ukuran gambar kertas gambar kerja yang lebih besar, PIHAK KEDUA akan mengajukan klaim atas biaya pencetakan dokumen tersebut.

c. Tahap Pengembangan Desain, yang terdiri dari:

1) Pengembangan/penyempurnaan gambar-gambar desain skematik

2) Gambar-gambar terintegrasi anatara arsitektur \& engineering \& bidang lain

3) Gambar mengacu pada pemakaian material bangunan/teknik konstruksi

d. Tahap Penyusunan Desain Terinci untuk Pelelangan Konstruksi dan Pelaksanaan Konstruksi, yang terdiri dari:

1) Pembuatan gambar-gambar detail;

2) Pembuatan Rencana Kerja dan Syarat (RKS) Teknis;

Pihak kedua dalam hal ini adalah seorang Arsitek memiliki kewajiban untuk menciptakan desain arsitektur sebagaimana hal tersebut merupakan lingkup kerja arsitek dalam perjanjian. Pada KI terdapat hak eksklusif, yaitu hak yang hanya dimiliki oleh pemilik KI dan tidak seorang pun berhak menikmatinya tanpa izin pemiliknya. Hak eksklusif meliputi hak ekonomi dan hak moral. Namun dalam kontrak perjanjian pada Pasal 4 ayat (1) dan ayat (2) mengatur mengenai kepemilikan Hak Cipta atas karya desain arsitektur tersebut sebagai berikut:

(1) Seluruh rancangan, gambar - gambar, spesifikasi, disain, laporan dan dokumendokumen lain serta piranti lunak hasil kerja PIHAK KEDUA akan menjadi hak milik PIHAK KESATU setelah berakhir dan terpenuhinya kewajiban sesuai Surat Perjanjian ini, dipergunakan dan dimanfaatkan oleh PIHAK KESATU sebagaimana peraturan perundang - undangan.

(2) PIHAK KEDUA wajib membebaskan PIHAK KESATU dari segala tuntutan atau klaim dari pihak ketiga yang disebabkan penggunaan HAKI oleh PIHAK KEDUA.

Jika dari perspektif Hak Cipta dalam prinsip alter ego prinsip yang meletakkan dasar pengakuan ekonomi maupun hak moral dari pencipta, sehingga pencipta mempunyai hak alamiah untuk memanfaatkan ciptaannya. Pada hakikatnya prinsip alter ego menempatkan inventor sebagai pihak yang tinggi kedudukannya dan tidak bisa diganggu gugat kepemilikannya terhadap suatu invensi yang diciptakannya karena prinsip alter 
egomerefleksikan diri pencipta itu sendiri. Dalam praktik penjanjian yang mengatur mengenai kepemilikan Hak Cipta bahwa desain arsitektur yang telah diperjanjian tersebut antara PT. RI dengan PT. CRN seharusnya kepemilikan hak cipta tersebut tetap berada pada pihak kedua, karena hak cipta adalah hak esklusif bagi pencipta yang terdapat hak ekonomi dan hak moral di dalamnya, ditinjau dari hak ekonomi hak cipta dapat berpindah ketika didalamnya terdapat keuntungan materil bagi pencipta dan telah diperjanjikan oleh para pihak. Namun dalam Pasal 5 ayat (2) UUHC bahwa hak moral sebagaimana dimaksud pada ayat (1) tidak dapat dialihkan selama Pencipta masih hidup, tetapi pelaksanaan hak tersebut dapat dialihkan dengan wasiat atau sebab lain sesuai dengan ketentuan peraturan perundang-undangan setelah Pencipta meninggal dunia. Ditinjau dari hak moral yang tercantum dalam UUHC bahwa sebetulnya kepemilikan hak cipta tidak dapat beralih kepada pihak kesatu walaupun telah diperjanjikan oleh pihak kesatu dan pihak kedua. Selain itu bahwa karya cipta harus tetap berada pada pencipta sebagai arsitek hal tersebut diperkuat dalam Undang - Undang No. 6 Tahun 2017 Tentang Arsitek Pasal 21 huruf (c) dimana arsitek memiliki kewajiban mendaftarkan hak kekayaan intelektual atas hasil karyanya. ${ }^{25}$

Artinya apabila implikasi dari penerapan prinsip alter ego pada perjanjian antara pengembang proyek dan arsitek, terhadap segala keuntungan dari pemanfaatan karya desain arsitektur merupakan hak dari arsitek. Arsitekharus diperlakukan sebagai pihak yang memiliki kedudukan dan sifat koordinatif dengan perusahaan pengembang. Hal ini mengingat arsitek memiliki keahlian khusus yang tidak dimiliki perusahaan pengembang atau pihak lain yang terlibat dalam proyek tersebut. Arsitek memiliki kemampuan yang khas, kuat, dan membedakan serta menentukan dalam bidangnya (most characteristic). Dengan demikian, kedudukan arsitek dalam perjanjian adalah setara dengan perusahaan pengembang. Kegiatan merancang suatu desain arsitektur bangunan memerlukan keahlian dengan kualifikasi tertentu sebagai arsitek, yang berbeda dengan kegiatan lain dalam proyek. Arsitek yang melahirkan ide atau desain arsitektur merupakan pihak yang bersifat koordinatif atau setara dengan perusahaan pengembang. Dalam kerangka perjanjian yang

${ }^{25}$ Pasal 21 huruf (c) Undang-Undang No. 6 Tahun 2017 Tentang Arsitek 
telah di sepakati oleh para pihak dalam hal ini antara PT. RI dengan PT. CRN jika dilihat dari sisi hukum perjanjian yang menganut kebebasan berkontrak ${ }^{26}$ bahwa terjadinya perjanjian sah apabila terpenuhinya syarah sah perjanjian menurut Pasal 1320 Kitab Undang-Undang Hukum Perdata meliputi sepakat mereka yang mengikatkan diri, kecakapan untuk membuat suatu perikatan, suatu hal tertentu, Suatu sebab yang halal. Dua syarat pertama merupakan syarat subjektif dalam syarat sahnya perjanjian karena kedua syarat tersebut ditujukan kepada personal atau orang - orangnya.

Syarat sahnya perjanjian yang ketiga adalah adanya suatu hal tertentu yang dimaksud mengenai suatu hal tertentu, artinya ialah apa yang akan diperjanjikan harus jelas dan terinci (jenis, jumlah dan harga) atau keterangan terhadap objek, diketahui hak dan kewajiban tiap-tiap pihak, sehingga tidak terjadi suatu perselisihan antara para pihak. Syarat keempat adalah adanya suatu klausa yang halal, klausa halal yang dimaksud adalah isi dari perjanjian itu tidak bertentangan dengan ketertiban umum, kesusilaan, dan Undang-Undang. ${ }^{27 S e b a b ~ d i k a t a k a n ~ t e r l a r a n g ~ j i k a ~ b e r t e n t a n g a n ~ d e n g a n ~ U n d a n g-U n d a n g, ~}$ kesusilaan, dan ketertiban umum. Misalnya, tidak dipenuhinya ketentuan pasal Pasal 5 ayat (2) UU No. 28 Tahun 2014 dapat dikategorikan sebagai suatu bentuk pelanggaran dalam undang-undang. Oleh karena itu, dalam isi pasal tersebut dinyatakan bahwa Hak moral sebagaimana dimaksud pada ayat (1) tidak dapat dialihkan selama Pencipta masih hidup, tetapi pelaksanaan hak tersebut dapat dialihkan dengan wasiat atau sebab lain sesuai dengan ketentuan peraturan perundang-undangan setelah Pencipta meninggal dunia. Namun secara praktik yang terjadi perjanjian antara pihak pengguna jasa arsitek dengan arsitek adalah kepemilikan Hak Cipta yang seharusnya berada pada seorang aristek tetapi kepemilikan Hak Cipta tersebut menjadi milik pihak pengguna jasa sebagaimana yang tertuang didalam perjanjian Pekerjaan Jasa Konsultasi Perencanaan Teknis Terinci Pekerjaan Arsitektur (PJKPTT-PA) pada Pasal 4 ayat (1) Seluruh rancangan, gambargambar, spesifikasi, disain, laporan dan dokumen - dokumen lain serta piranti lunak hasil

\footnotetext{
26 Semua persetujuan yang dibuat secara sah berlaku sebagai undang - undang bagi mereka yang membuatnya, pasal 1338 Kitab Undang-Undang Hukum Perdata (Burgerlijk Wetboek) diterjemahkan oleh R. Subekti dan S. Tjitrosudibio cet. 32, Pradnya Paramita, Jakarta, 2002

27 Fajar Bayu Setiawan, 2013, Himma Asihsalista, Nikki Ramadhani M. Pranoto, “Kedudukan Kontrak Sewa Rahim dalam Hukum Positif Indonesia", Private Law, ed. 1, 2013, hlm. 70.
} 
kerja PIHAK KEDUA akan menjadi hak milik PIHAK KESATU setelah berakhir dan terpenuhinya kewajiban sesuai Surat Perjanjian ini, dipergunakan dan dimanfaatkan oleh PIHAK KESATU, kemudian pada ayat (2) PIHAK KEDUA wajib membebaskan PIHAK KESATU dari segala tuntutan atau klaim dari pihak ketiga yang disebabkan penggunaan HAKI oleh PIHAK KEDUA.

Dari isi perjanjian tersebut terlihat bahwa ada yang bertentangan dengan Pasal 5 Undang-Undang No. 28 Tahun 2014 Tentang Hak Cipta mengenai hak moral, disamping itu hak ekslusif yang meliputi hak ekonomi dan hak moril menjadi dikesampingkan karena dengan dimilikinya hak cipta pada pihak pengguna jasa hal tersebut sama saja dengan mengenyampingkan atau melanggar hak moral yang melekat pada pencipta. Dengan begitu secara otomatis perjanjian antara pihak penggunasa jasa dengan arsitek dapat dinyatakan "Batal Demi Hukum", dengan alasan perjanjian tidak memenuhi syarat sah pada pasal 1320 yaitu "suatu sebab yang halal". 28

\section{PENUTUP}

Berdasarkan Pasal 36 Undang-Undang No. 28 Tahun 2014 Tentang Hak Cipta menyatakan bahwa kecuali diperjanjikan lain, Pencipta dan Pemegang Hak Cipta atas Ciptaan yang dibuat dalam hubungan kerja atau berdasarkan pesanan yaitu pihak yang membuat Ciptaan dijelaskan bilamana karya cipta desain arsitektur dibuat berdasarkan pesanan dalam hal ini developer perumahan sebagai pemesan jasa arsitek maka pihak pemesan jasa yaitu pihak yang dianggap membuat ciptaan, artinya dalam pasal tersebut memungkinkan kepemilikan hak cipta beralih dari pencipta kepada pihak lain. Selanjutnya berdasarkan Pasal 5 ayat (2) Undang-Undang No. 28 Tahun Tentang Hak Cipta menjelaskan bahwa hak moral yang melekat pada pencipta tidak memungkinkan beralihnya hak. Jika mengacu kepada prinsip alter ego yang menjunjung tinggi kepemilikan hak cipta melekat pada pencipta maka dalam pasal 36 terebut kurang sesuai dengan prinsip alter ego yang seharusnya dijadikan rujukan dalam pembentukan undang- undang.

${ }^{28}$ Buletin Len, 2014, Ed. No.15, PT Len Industri, Maret, hlm. 50. 
Dari isi perjanjian antara PT. RI dengan PT. CRN terlihat bahwa ada yang bertentangan dengan Pasal 5 Undang - Undang No. 28 Tahun 2014 Tentang Hak Cipta mengenai hak moral, disamping itu hak ekslusif yang meliputi hak ekonomi dan hak moril menjadi dikesampingkan karena dengan dimilikinya hak cipta pada pihak pengguna jasa hal tersebut sama saja dengan mengenyampingkan atau melanggar hak moral yang melekat pada pencipta. Dengan begitu secara otomatis perjanjian antara pihak penggunasa jasa dengan arsitek dapat dinyatakan "Batal Demi Hukum", dengan alasan perjanjian tidak memenuhi syarat sah pada pasal 1320 yaitu "suatu sebab yang halal. Terdapat perbedaan antara ketentuan undang-undang dengan prakteknya dilapangan, ketika ciptaan arsitektur dibuat dalam suatu hubungan kerja, dalam prakteknya menjadi tidak jelas pihak mana yang berhak atas kepemilikannya. Hal ini dapat dibuktikan dengan belum pernah ada pendaftaran hak cipta arsitektur di Indonesia. Padahal pendaftaran bertujuan untuk mendapatkan catatan formal status kepemilikan hak cipta, terutama untuk mendukung pembuktian dalam hal terjadi sengketa kepemilikan hak cipta dan Pengadilan di Indonesia belum pernah menangani kasus hukum seorang arsitek mempersoalkan plagiarisme arsitek lain terhadap bangunan yang dibuatnya, ataupun arsitek mempersoalkan perusahaan tempatnya bekerja.

\section{DAFTAR PUSTAKA}

\section{Buku}

Abdul Kadir Muhammad, 2001. Kajian Hukum Ekonomi Hak Kekayaan Intelektual, PT. Citra Aditya Bakti, Bandung.

Budihardjo, E, 1997. Arsitek dan Arsitek Indonesia Menyosong Masa Depan. Andi, Yogyakarta.

Cst Kansil, Christine, S.T Kansil, Engelien R, Palandeng dan Godlieb N Mamahit, 2009. Kamus Istilah Hukum, Jakarta.

Eddy Damian, 2005. Hukum Hak Cipta, Edisi Kedua Cetakan ke-3, Bandung: Alumni.

Eko Budihardjo, 1987. Arsitek Bicara Tentang Arsitektur Indonesia, Alumni, Bandung.

Ermansyah Djaja, 2009. Hukum Hak Kekayaan Intelektual, Sinar Grafika, Jakarta.

Haris Munandar dan Sally Sitanggang, 2008. Mengenal HAKI Hak Kekayaan Intelektual Hak Cipta, Paten dan Seluk beluknya, Erlangga, Jakarta. 
J.F. O'Gorman, 1997. ABC of Architecture, Philadelphia: University of Pennsylvania Press.

Satjipto Raharjo, 2000. Ilmu hukum, Bandung: Citra Aditya Bakti.

Soerjono Soekanto, 1986. Pengantar Penelitian Hukum, UI Press, Jakarta.

Peter Mahmud Marzuki, 2008. Pengantar Ilmu Hukum, Kencana, Jakarta.

\section{Jurnal}

Fajar Bayu Setiawan, Himma Asihsalista, Nikki Ramadhani M. Pranoto, 2013. “Kedudukan Kontrak Sewa Rahim dalam Hukum Positif Indonesia", Private Law, ed. 1, 2013.

Lusi Indah W. 2007. Keragaman Persepsi Terhadap Arsitektur, Jurnal Arsitektur, Vol. 1, No. $2,2007$.

Reni Budi Setianingru, 2016. Mekanisme Penentuan Nilai Ekonomis dan Pengikatan Hak Cipta Sebagai Objek Jaminan Fidusia, Media Hukum, Vol. 23 No. 2, Desember, 2016.

Tata Wijayanta, 2014, Asas Kepastian Hukum, Keadilan dan Kemanfaatan Dalam Kaitannya Dengan Putusan Kepailitan Pengadilan Niaga, Fakultas Hukum Universitas Gadjah Mada Yogyakarta, Jurnal Dinamika Hukum Vol. 14 No. 2 Mei 2014.

Yasir Arfan, 2013. Status Kepemilikan Hak Cipta Arsitektur yang dibuat Berdasarkan Hubungan Kerja (Suatu Penelitian di Kota Medan). Premise Law Jurnal. Vol 1, No 2 (2013).

\section{Peraturan Perundang-Undangan}

Undang-Undang Nomor 6 Tahun 2016 Tentang Arsitek.

Undang-Undang No. 28 Tahun 2014 Tentang Hak Cipta.

Kitab Undang-Undang Hukum Perdata Indonesia.

\section{Sumber Lain}

Buletin Len, Ed. No.15, PT Len Industri, Maret, 2014.

Enrico Endy Siagian, Implementasi Prinsip Alter Ego Peneliti Sebagai Hak Ekonomi Paten Aparatur Sipil Negara (ASN) Berdasarkan Undang- Undang Nomor 14 Tahun 2001 Tentang Paten, dalam Jurnal Hukum Unpad. 